\title{
Got Technology? The Impact of Computers and Cell-phones on Productivity in a Difficult Business Climate: Evidence from Firms with Female Owners in Kenya
}

\author{
Nidhiya Menon \\ Brandeis University
}

Version: December 17, 2010

\begin{abstract}
Firms in Kenya rely on technologies such as computers, cell-phones, and generators to overcome constraints associated with regulations, infrastructure, security, workforce, corruption, and finance. This study shows that such reliance has significant positive impacts on productivity as measured by valueadded per worker, especially for firms with female principal owners. The exogenous component of technology ownership is isolated by using information on the regional presence of missionary schools from Kenya's colonial past, as well as geographical indicators such as rainfall, changes in forest cover, and average regional elevation. Results indicate that for firms with female owners, technology adoption improves value-added per worker by about 49 percentage points. It is also statistically evident that for such firms, the ownership of technologies such as computers, cell-phones, and generators succeeds in mitigating the costs of business obstacles. For male-owned firms, such patterns are absent.
\end{abstract}

Keywords: Technology, Computers, Cell-phones, Business Obstacles, Kenya, Firms, Female Owners JEL Classification Codes: O14, O33, L22, N37

This research has benefitted from comments of participants at a seminar at Wellesley College. Rachel McCulloch provided comments on an earlier draft. Jing Ren provided capable research assistance. Address for correspondence: MS 021, Department of Economics, Brandeis University, Waltham, MA 02454. Tel. no.: 781.736.2230, email: nmenon@ brandeis.edu. 


\section{Section 1: Introduction}

Firms in Africa face large operation costs due to regulatory and infrastructural hurdles. These include long delays in gaining access to telephone land-lines, electricity, and water connections, informal payments and gifts that are required in order to expedite and obtain licenses and government contracts, and insecure, unstable operating environments. When such obstacles to business exist, firms may rely on technology to overcome many of the hurdles faced. For example, if there are significant delays in obtaining mainline telephone connections, firms may opt to rely on technologies such as cell-phones and computers to conduct business, and use email and the internet for communication and advertisement purposes. When the supply of electricity is unreliable, firms may invest in generators. Furthermore, if crime is rampant, firms may pay for security and security equipment to protect their businesses. These examples indicate that the use of technologies such as cell-phones, computers, generators, are endogenous to obstacles posed by excessive regulations and poor infrastructure.

In dealing with the constraints presented by restrictive regulations and lack of infrastructure and services, it may be argued that firms with female owners are at an even greater disadvantage. This is because women-owned businesses tend to be more credit-constrained that those run by men. Moreover, unlike firms operated by men, women-owned businesses are often isolated from formal and informal networks that provide information and support. Women-run businesses also tend to be of smaller scale. For these reasons, giving gifts or making informal payments to expedite licenses for operating businesses or accessing telephone land-lines may pose a greater hardship for such firms.

Since women-owned firms face higher costs of operation, intuitively, one should expect different patterns in their reliance on technology as compared to male-owned businesses. Menon (2010) analyzes the effect of obstacles on technology use and finds that while all firms rely on technology in the face of obstacles related to regulations, infrastructure, workforce, security, and corruption, firms with female principal owners experience net effects that are statistically different from those experienced by firms with only male principal owners. In particular, estimates from the full sample of firms indicate that the

probability of technology ownership is 0.15 higher for firms with female owners as compared to all other 
firms. Moreover, a test for the joint significance of terms that involve interactions of the female headship variable and six different obstacles indicates that the null hypothesis of insignificance can be rejected. That is, firms with female owners experience net effects of obstacles that are distinct from firms with allmale owners. Finally, a gender-of-owner disaggregated Oaxaca-Blinder type decomposition of differences in technology ownership in a smaller subset of industries reveals that up to $18 \%$ of the total gap is due to differences in preferences (residual component). This suggests that female-owned firms own technology to a higher level than is consistent with their observed characteristics.

Menon (2010) sketches the business environment in Kenya and shows that in such an environment, technology use is endogenous with respect to the obstacles that exist. The aim of this study is to analyze whether conditional on business obstacles, region, firm, and industry covariates, technology ownership has significant impacts on firm productivity. This is an important question since evidence of the productivity-enhancing effects of technology ownership provides a compelling rationale for why firms choose to invest in tools such as computers, cell-phones, and generators, in difficult business circumstances where regulations are binding, infrastructure is poor, and there are large overheads associated with corruption and insecurity. Menon (2010) documents a behavior that exists in the restrictive business climate of Kenya - reliance by establishments, especially female-owned ones, on technologies such as computers and cell-phones. This research provides evidence that such reliance has important measurable effects on firm productivity, that is, firms that choose to invest in such technologies are more successful in overcoming the restraining influences of the harsh business background in Kenya.

Using the World Bank's Enterprise Survey data from 2007 on Kenyan manufacturing firms, retail firms, and micro-enterprises, this research demonstrates that the ownership and use of technology such as computers, generators, and cell-phones have beneficial impacts on firm productivity as measured by value-added per worker, particularly in establishments that are female-headed. Using a two-stage methodology where geographical indicators and historical measures of education from Kenya's colonial past are used as identifying instruments, this study shows that conditional on obstacles, regional, firm, industry, and top manager covariates, ownership of computers, generators, and cell-phones in Kenya has 
large, positive, and significant effects on value-added per worker. For all firms, a one unit increase in the average measure of technology increases value-added per worker by about 86 percentage points.

However, most of this is for firms that are female-headed, where the effect of technology is positive and significant but lower in magnitude at 49 percentage points. Consistent with this, a joint test of the significance of all obstacles cannot be rejected. That is, conditional on technology ownership, obstacles to business have no statistical impact on value-added per worker in firms that are female-owned.

Interestingly, the effect of technology ownership is positive but measured imprecisely in the sample of firms with male-only owners. This is evidence in favor of the assertion that female-owned firms stand to gain the most from technology adoption in Kenya.

\section{Section 2: Review of previous research}

Menon (2010) provides a review of the literature on the effect of regulatory obstacles on technology adoption in developed and developing countries. In general, these studies have mainly been theoretical in nature for advanced countries (Acemoglu and Autor, 2010, Alesina and Zeira, 2009, and Acemoglu et al., 2007). In terms of the developing world, most studies have concentrated on the adverse economic impacts of restrictive labor legislations (Almeida and Carneiro, 2009, Lall and Mengistae, 2005, Menon and Sanyal, 2005, and Besley and Burgess, 2004), and one has focused on the effect of such legislations on computer ownership (Amin, 2009).

The effect of technology adoption (as embodied in computers) on firm productivity in advanced countries is well documented. Stoneman and Kwon (1996) uses data on firms from the UK to study the diffusion of technology to show that non-adopters experience lower profits as other firms adopt new technologies such as computer numerically controlled machine tools and computers used for administrative purposes. Brynjolfsson and Hitt (2000) notes the wider applicability of the computer as being a tool that is effective in many other things than just the ability to compute quickly. In particular, the study notes the productivity enhancing effects of computer-controlled machinery that is documented in Keller (1994), and the improvement in productivity of government services such as toll collections that has resulted from increased computerization (Mukhopadhyay et al., 1997). Further, Black and Lynch 
(2001) shows that plant productivity is higher when a larger proportion of non-managerial staff use computers, whereas Bresnahan, Brynjolfsson, and Hitt (2002) finds that use of technologies such as computers and telecommunications equipment works in a complementary manner with workplace reorganization to increase productivity and the demand for skilled labor.

There is little previous work on developed countries that has considered the adoption of technology as a means of mediating the effects of constraints such as excessive regulations. The few studies that have looked at technology, productivity, and regulations in the same context either consider only the negative effects of regulations on productivity (Scarpetta and Tressel, 2002), or why technology adoption has been low in industrial countries other than the US. Gust and Marquez (2004) in particular attributes the latter to stringent regulations.

In the developing world, the impact of technological innovation has either been studied in the context of research and development (R\&D) or foreign direct investment. For example, Basant and Fukkert (1996) finds that an Indian firm's returns to internal R\&D expenditures are often low and insignificant, whereas its returns to technology purchases have large, statistically significant impacts on output. Vishwasrao and Bosshardt (2001) finds that an Indian firm's probability of adopting new technology is largely dictated by foreign ownership and firm size. Using data on firms from China, Hu and Jefferson (2005) documents that the effect of foreign technology transfer on firm's productivity depends on the manner in which such transfers interact with internal R\&D. In the context of Africa, a few studies have analyzed the association between technology and productivity (Harding and Rattso, 2005, Goedhuys et al. 2006), but none have considered the role of technology in mitigating the constraining influences of regulations and inadequate infrastructure on firm productivity

This research contributes to the literature by highlighting the role that technology can play in alleviating the costs of excessive regulations and poor infrastructure in a developing country. More specifically, it considers regulations, technology adoption, and firm productivity together, and analyzes the impact of technologies such as computers, cell-phones, and generators on firm productivity in difficult business environments. The results indicate that such technologies have large positive effects on value- 
added per worker, conditional on business obstacles related to regulations, infrastructure, workforce, security, corruption, and finance, as well as region, firm, and industry characteristics. A disaggregation of effects by gender-of-owner shows that firms with female headship are particularly advantaged from owning technology. To the best of our knowledge, this research is the first to document the assuaging role of technology on firm productivity in the face of regulatory and other business obstacles in Africa.

\section{Section 3: Theoretical framework}

This section formulates a theoretical model for understanding the manner in which adoption of technologies such as computers, cell-phones, and generators, affects a firm's value-added in environments with obstacles to business. ${ }^{1}$ This is simple model since the objective is to provide a straightforward theoretical structure for the estimations that follow. The basic intuition is the following: in the case of a short run or restricted value-added function (Varian, 1992), for constant output price and fixed production function, value-added is higher when total cost is lower. We consider the short run case since in the longrun, it is possible that choice of technologies directly affects the production process itself, as well as the choice of inputs. ${ }^{2}$ Total costs are lower with use of technologies such as computers and cell-phones since use of such technologies reduces the cost (price) of inputs. Consider communication, which is different from traditional inputs such as labor and capital, but clearly important in a firm's production process. The costs of communication can be high in environments with excessive regulations and long delays in obtaining basic services such as mainline telephone connections, and owning computers or cell-phones can decrease this cost. ${ }^{3}$ Consider a firm with the following production function:

$$
y=x_{1}^{a} x_{2}^{b}
$$

Where $y$ is output, $x_{1}$ is a conventional input such as labor, and $x_{2}$ is another input important for production such the ability to communicate easily with clients and suppliers. Where $w_{1}$ and $w_{2}$ are the factor prices associated with $x_{1}$ and $x_{2}$ respectively, the firm's cost minimization problem before it owns any technology is:

$$
\min w_{1} x_{1}+w_{2} x_{2}
$$




$$
\text { Such that } x_{1}^{a} x_{2}^{b}=y
$$

It is straightforward to see that the conditional demand for the conventional factor is:

$$
x_{1}=\left[\frac{a w_{2}}{b w_{1}}\right]^{\frac{b}{a+b}} y^{\frac{1}{a+b}}
$$

and conditional demand for the "communications" factor is:

$$
x_{2}=\left[\frac{a w_{2}}{b w_{1}}\right]^{\frac{-a}{a+b}} y^{\frac{1}{a+b}}
$$

Substituting these values into the cost function, we obtain:

$$
C_{1}^{*}=\left[\left(\frac{a}{b}\right)^{\frac{b}{a+b}}+\left(\frac{a}{b}\right)^{\frac{-a}{a+b}}\right] w_{1}^{\frac{a}{a+b}} w_{2}^{\frac{b}{a+b}} y^{\frac{1}{a+b}}
$$

In the case of a constant returns to scale Cobb-Douglas production function, (3) reduces to

$$
C_{1}^{*}=a^{-a}(1-a)^{a-1} w_{1}^{a} w_{2}^{1-a} y
$$

since $a+b=1 .{ }^{4}$ If adopting technology such as a cell-phone reduces the cost of communication for a firm, then equation (2) can be re-written as:

$$
\begin{aligned}
& \min w_{1} x_{1}+\left(w_{2}-\tau\right) x_{2} \\
& \text { Such that } x_{1}^{a} x_{2}^{b}=y
\end{aligned}
$$

Where $\tau$ is the "price-offset" that technology brings, with $\tau>0$ and $\tau<w_{2}$. The $\tau<w_{2}$ assumption states that firms still have some costs associated with the communications input; these are not driven to zero by virtue of technology ownership. ${ }^{5}$ The effective price of the communication input $x_{2}$ is now $\left(w_{2}-\tau\right)<w_{2}$. It is relatively easy to show that solving the problem in (5) leads to the following optimal cost function:

$$
C_{2}^{*}=a^{-a}(1-a)^{a-1} w_{1}^{a}\left(w_{2}-\tau\right)^{1-a} y
$$

Comparing (4) and (6), we can see that the costs in (6) will be lower than those in (4). In order to show this more formally, consider the following restricted value-added functions faced by a firm without $\left(\pi_{1}(p, w)\right)$ and with the cell-phone $\left(\pi_{2}(p, w)\right)$ :

$$
\pi_{1}(p, w)=\max p y-C_{1}^{*}
$$




$$
\pi_{2}(p, w(\tau))=\max p y-C_{2}^{*}
$$

where $p$ is the sale price of output, and $w$ is a vector of input prices. Adoption of technology has a positive effect on value-added in the short run when $\pi_{2}(p, w(\tau)) \geq \pi_{1}(p, w)$, which is consistent with $\left(\frac{C_{1}^{*}}{C_{2}^{*}}\right) \geq 1$. Taking the ratio of equations (4) and (6) we obtain:

$$
\left(\frac{C_{1}^{*}}{C_{2}^{*}}\right)=\left(\frac{w_{2}}{\left(w_{2}-\tau\right)}\right)^{1-a}
$$

It is clear that $\left(\frac{w_{2}}{\left(w_{2}-\tau\right)}\right)^{1-a} \geq 1$ since $\tau<w_{2}$ and $a<1$. Conditional on regulatory, infrastructural, and other business obstacles, as well as region, firm and industry covariates, we test the productivity (valueadded per worker) enhancing effect of technologies such as computers, cell-phones, and generators in the following sections of the paper.

\section{Section 4: Empirical methodology}

Menon (2010) provides evidence that technology ownership is endogenous in the business environment of Kenya. That is, ownership of technologies such as computers, cell-phones, and generators is influenced by business obstacles, controlling for other firm and industry characteristics. This implies that estimating the effect of technology on firm productivity with methods such as OLS is likely to result in flawed estimates. In fact, if technology ownership is more likely in the face of regulatory and infrastructural constraints, then OLS will over-estimate the true impact of technology on firm productivity. In order to avoid such bias, we instrument for technology ownership in order to isolate its exogenous component and ascertain whether ownership of technology has positive effects on firm productivity. We accomplish this using standard linear two stage least squares (TSLS) models in which the first stage is of the following form:

$$
T_{i j}=\gamma_{0}+\gamma_{1} Z_{i j}+_{\vartheta_{i j}}
$$

where $i$ denotes a firm and $j$ denotes a region/city, $T_{i j}$ is the average of an indicator for whether firm $i$ in region $j$ owns a computer, generator, and cell-phone (our need to take averages is explained below), and 
$Z_{i j}$ are the identifying instruments (also discussed below). Results of equation (8) are reported in Table $3 \mathrm{~A}$.

The second stage of the two stage framework includes the orthogonal component of $T_{i j}$ and is characterized by:

$$
\begin{gathered}
V_{i j}=\beta_{0}+\beta_{1} \widehat{T}_{i j}+\beta_{2} O_{i j}+\beta_{3} F_{i j}+\beta_{4}\left(F_{i j} * O_{i j}\right)+\beta_{5} R_{j} \\
+\beta_{6} X_{1 i j}+\beta_{7} X_{2 i j}+\varepsilon_{i j}
\end{gathered}
$$

Where $V_{i j}$ is value-added per worker (our measure of firm productivity), $\widehat{T}_{i j}$ is the predicted value of the dependent variable in (8), $O_{i j}$ is a vector of variables that represents six obstacles faced by the firm (obstacles related to regulations, infrastructure, workforce, security, corruption, and finance), $F_{i j}$ is an indicator for whether the firm has one or more female principal owners, $R_{j}$ are regional (city) dummies, $X_{1 i j}$ represents firm and industry characteristics, $X_{2 i j}$ represents the firm's top manager's characteristics, and $\varepsilon_{i j}$ is the standard error term. For all firms, $\beta_{1}$ is the impact of technology on value-added per worker. We disaggregate the firm-level data by gender-of-owner, and run equation (9) separately for the two sub-samples to ascertain the relative size of $\beta_{1}$ for firms that have female principal owners and those that do not. As is obvious, $\beta_{3}$ indicates how value-added per worker differs between firms with female owners and those that have only male owners. Finally, in (9), the net amplified effect of obstacles on the dependent variable for firms with female owners is measured by $\left(\beta_{2}+\beta_{4}\right)$. The instrumental variables (IV) results are reported in Table 4.

\section{Section 5: Data and descriptive statistics}

Data used in this research are from the Enterprise Survey which was implemented by the World Bank in Kenya in 2007. In Kenya, the firms that were targeted were located in the capital city of Nairobi which is in the central part of the country, the coastal city of Mombasa, Nakuru in the Rift Valley, and Kisumu which is located near Lake Victoria in the Western region of the country (see Map 2). Nairobi, Mombasa, Nakuru, and Kisumu were selected since they collectively contain the largest share of economic activity in Kenya. Firms in all manufacturing sectors, construction, retail and wholesale 
services, hotels and restaurants, transport, storage, and communications, and computer and related activities were administered the survey. Those that had five or more full-time permanent paid employees were stratified into five groups: manufacturing (food and beverages), manufacturing (garment), manufacturing (other), retail trade, and "rest of the universe" (RoU) which included construction, wholesale trade, hotels, bars and restaurants, transportation, storage, and communications, and computer related activities. Firms having fewer than five full-time permanent paid employees ("micro establishments") were also sampled; however, these were not stratified according to industry.

The Enterprise Survey asks detailed questions on the environment faced by firms in conducting business within their regions of operation. These questions include those related to firm characteristics, gender participation, sales, costs of inputs, and obstacles related to telecommunications, crime, licensing, infrastructure, trade, competition, land and permits, taxation, access to finance, zoning restrictions, and other restrictions on hours of operation and pricing and mark-ups. Given the level of detail in the survey, these data are particularly relevant for purposes of this study.

The sampling methodology employed is stratified random sampling with replacement, where the strata are firm size (number of employees), business sector (manufacturing, retail, and other services), and geographic region within the country. All estimations as well as summary statistics are adjusted with sampling weights provided in the data to account for the differing probabilities of selection across the different strata.

Menon (2010) indicates that these data are less useful to address questions on access to entrepreneurship as it includes a random sample of firms that have overcome barriers to entry and have "survived" to remain in existence. This is an issue that conceivably plagues any cross-sectional data set that samples from the private sector of a developing economy. One implication of this is that firms with female owners in the complete sample may be less representative of the average women-owned firm in the economy. A way to increase such comparability is to restrict the analysis to firms in industries where barriers to entry for women are comparatively low. These industries include manufacturing industries such as garments, food, textiles, and non-metallic minerals (these include gemstones and gold, which is 
mainly processed by small-scale artisanal workers in the Western and South-Western regions of the country near Lake Victoria), retail industries, and service industries such as hotels and restaurants, and construction and transport. We also exclude all firms that are legally classified as "public" since Figure 3 of Menon (2010) suggests that such firms are not representative of Kenya's economy which is mostly dominated by small and medium enterprises. With these sample restrictions, we are confident that the indicator for firms with female owners is representative. Our estimation sample thus has 499 firm-level observations, of which 213 firms have female principal owners and 286 firms have only male principal owners.

Figure 1 depicts the percentage of firms with female principal owners and those without, by industries. The figure is arranged such that classifications that have the largest difference between female-owned and male-owned firms appear first. In our sample, the largest difference by gender of firm owner is found in manufacturing garment industries ( $22.5 \%$ female, $15 \%$ male-only) followed by retail industries (32.4\% female, $31.8 \%$ male-only). Textiles have relatively the same proportion of female and male headed firms, and the proportion of firms with only-male owners exceeds that of female-owned firms in non-metallic minerals, construction and transport, and hotels and restaurants. Figure 1 shows that the fewest relative number of firms with female owners is found in manufacturing food industries.

Figure 2 shows the breakdown of firms by gender-of-owner and use of technology. The technologies considered in this research are computer (the firm uses email or has its own web-site or has an internet connection), generator (the firm owns or shares a generator), and cell-phone (the firm uses cell-phones for communication with clients and suppliers) combined. ${ }^{6}$ As noted above, about $43 \%$ of firms in these data have one or more female principal owners. In such an environment, it is remarkable to note that firms with female owners rely on computers, cell-phones, and generators to such a disproportionately large extent. Figure 3 shows that the proportion of female firms that own technologies of the form considered here is about $96 \%$ of the proportion of male firms that also owns such technologies. Correspondingly, although firms with female owners exceed those with male-only owners among establishments that do not own any technology, the difference is almost imperceptible (39.4\% 
female to $36.7 \%$ male-only). The patterns in Figure 2 indicate that in Kenya, female-owned firms depend on computers, cell-phones, and generators to a relatively high extent as compared to firms with only male-owners.

Figure 3 is a plot of the median value-added per worker (in 2006 US \$) for firms with female principal owners and for those without. It is apparent from this figure that value-added per worker is approximately the same for male-owned and female-owned firms for the majority of industries in the sample. In particular, value-added per worker in male and female firms is about the same in garments, food, textiles, and comparable, although to smaller degree, in retail firms and firms in the hotels and restaurants industry. Value-added per worker is significantly different between male and female owned firms in two industries - non-metallic minerals (higher for female-owned firms) and construction and transport (higher for men-only owned firms). Figure 3 conveys that net of disadvantages that tend to work against female-owned firms (credit-constraints, small-scale, and relative isolation from supportproviding networks, which together act to compound the costs of obstacles related to regulation, infrastructure, security, and corruption), their value-added per worker is comparable to that of male-only owned firms for the majority of industries in our sample. The question of interest is how much of this is due to technology ownership.

Figures $1-3$ provide a graphical description of characteristics of firms in Kenya, disaggregated by gender-of-owner. They make clear that firms with female owners are mainly present in manufacturing garment and retail industries, and rely on computers, cell-phones, and generators to a larger degree than indicated by their presence in the estimation sample. Next, we focus on the obstacles that are perceived by firms in the business environment of Kenya.

The Enterprise Survey data report constraints related to twenty different types of obstacles. For expositional purposes, the twenty separate types of constraints are combined into six categories regulations, infrastructure, security, workforce, corruption, and finance. The regulations group includes the following obstacles: labor regulations, licensing and permits, customs and trade regulations, regulations on hours of operation, regulations on pricing and mark-ups, zoning restrictions, tax rates, and 
tax administration. The infrastructure group includes obstacles related to telecommunications, electricity, transportation, and access to land. The security category includes constraints related to crime, theft, and disorder, political instability, macroeconomic instability, and functioning of the courts. The workforce group includes obstacles related to an inadequately educated workforce, and the corruption group includes obstacles related to corruption and practices of competitors in the informal sector. The last group (finance) includes obstacles related to access to finance.

Tables 2A - 2D in Menon (2010) report unweighted numbers of firms characterizing obstacles as moderate, major, or very severe, by firm size, industry, and technology use. In the Enterprise Survey data, firms are asked to rank obstacles on a scale of five - no obstacle, minor obstacle, moderate obstacle, major obstacle, and very severe obstacle. The tables that follow (and those in Menon (2010)) report results for firms that denote constraints to be moderate, major, or very severe. It is clear from Menon (2010) that the vast majority of firms in the complete data report regulations, infrastructure, corruption, and security to be moderate, major, or very severe obstacles, in that order. For firms with female owners, the largest hurdles appear to be regulations, corruption, infrastructure and security.

Tables $1 \mathrm{~A}-1 \mathrm{C}$ below show weighted proportions of firms characterizing obstacles as moderate, major, or very severe, by industry and technology use in our sample. Table 1A shows that over $90 \%$ of firms report regulations, infrastructure, and finance to be a binding constraint, and this pattern is also true upon disaggregation by gender of firm owner. Table 1B shows weighted proportions by industrial groupings, and for firms with female headship, regulations continue to be the most widely cited obstacle across all industrial categories. Such firms in manufacturing and construction and transport are also particularly concerned with security and corruption, whereas firms that are male-owed in manufacturing are less likely to cite security as a major concern. Amongst firms with male-ownership, access to finance is the most widely cited obstacle after regulations. Finally, estimates in Table 1C show that firms who report using technology are also more likely to report regulations, corruption, and infrastructure to be binding obstacles. This remains true upon disaggregation by gender of owner as well. 
Tables $1 \mathrm{~A}-1 \mathrm{C}$ provide descriptive evidence that firms perceive excessive regulations, poor infrastructure, lack of security, and widespread corruption as imposing significant burdens in the business environment of Kenya. There are also correlations evident between the perception of these constraints and use of computers, cell-phones, and generators.

We conclude this section by reporting differences in obstacles and other firm and industry-level variables between female-headed and male-only headed firms. Obstacles measured in the data and discussed in tables $1 \mathrm{~A}-1 \mathrm{C}$ reflect a firm's perceptions of its operating environment. In order to eliminate possible measurement errors and other endogeneity issues that may contaminate these variables, we take averages of these variables at the region, industry, legal status, and firm size level (Angrist and Krueger 2001). The estimations discussed in the following tables are conducted on constructed mean values of the obstacles rather than an individual firm's perceptions of them. ${ }^{7}$

Table 2 provides weighted means and standard deviations of the characteristics of firms with female owners and those without, and an indication of whether there is a statistical difference in the characteristics. The characteristics reported include value-added per worker, ownership of technology (computer, generator, or cell-phone, where establishments are coded as owning a computer if they use email, or have their own web-site, or have an internet connection), obstacles related to regulations, infrastructure, security, workforce, corruption, and finance, the variables used as identifying instruments (discussed below), regional indicators, firm and industry characteristics including firm size, value of property and machinery, industrial classification, and finally, characteristics of the firm's top manager including education and number of years of experience in the sector. Estimates in this table indicate that on average, firms with female owners have lower value-added per worker (mostly from in the construction and transport industry) and slightly higher percentage values in terms of technology ownership as compared to male-only owned firms, although only the former is statistically significant.

The reported differences in obstacles for female-headed and male-only headed firms in Table 2 shows that the weighted average value is somewhat higher for female-owned firms in four of the six 
categories (regulations, infrastructure, security, workforce, and finance); however, these differences are not statistically significant.

Statistical differences in instruments and regional indicators by gender of firm owner are absent, although average values indicate that there are relatively fewer female-owned firms in Nairobi and relatively more of such firms in Mombasa. In terms of firm and industry characteristics, although femaleowned firms have lower machinery and property values, a higher value of percentage of establishment owned by largest shareholders, and relatively fewer proportions of manufacturing, retail, permanent fulltime paid employees, the difference is measured precisely only in the case of property values. There are no other instances of measurable differences in characteristics between female and male-owned firms in the remaining variables of Table 2 .

Results in Table 2 indicate that firms with female owners are not very different from firms with all-male owners in levels of technology chosen, or in terms of many of the firm, industry, and top manager characteristics considered. These categories of firms are thus comparable in terms of observed covariates.

\section{Section 6: Impact of technology ownership on firm productivity}

Menon (2010) shows that obstacles related to regulations, infrastructure, workforce, security, corruption, and finance, have significant effects on technology ownership. That is, all firms, especially those that have one or more female principal owners, rely on different forms of technology to overcome the limiting effects of obstacles. Menon (2010) also shows that up to $18 \%$ of the total difference in technology ownership between female-owned and male-owned firms cannot be attributed to differences in measured covariates. This is interpreted as evidence for the idea that in environments where regulations are excessive, infrastructure is inadequate, corruption is rife, and lack of security is pervasive, female-owned firms own technology to a greater degree than is warranted by their level of measured characteristics. They thus appear to "over-compensate", perhaps in order to counter-act the effects of firm-related unobservables or industry-related unobservables present in the environments in which they operate and to which they are particularly susceptible. 
Following the evidence in Menon (2010) that technology adoption is endogenous in difficult business circumstances, we provide estimates for the effect of such adoption on firm productivity in this section of the paper. As noted before, this is important since whether firms are successful in overcoming the restrictions imposed by obstacles in their operating environments can be ascertained only if the technology owned actually augments firm's productivity conditional on obstacles. However, also as noted above, the study of whether technology increases a firm's productivity is complicated by the fact that technology is endogenous in contexts where obstacles exist. Hence, instruments are required that are correlated with technology ownership, but conditional on technology adoption, do not affect firm productivity. We discuss these instruments below.

\section{Instruments for technology ownership}

\section{Regional distribution of missionary schools in Kenya from 1844 - 1935}

Operation of computers and cell-phones requires a basic amount of skills associated with recognizing letters from the English language, understanding Arabic numerals, and competence associated with elementary vocational training. The earliest foundations for such knowledge was laid by mission organizations in Kenya, primarily the Church Mission Society (CMS) which was founded in England in 1799, and which established the first school (mainly for the sons of local chiefs) in Rabai Mpia near Mombasa in 1844. Starting from 1844 through 1935, CMS and other missionary groups (Holy Ghost Mission, Church of Scotland Mission, Gospel Missionary Society, Consolata Society of Turin, Seventh Day Adventists, Quakers, Mill Hill Mission, Friends' Africa Mission, and the Protestant Alliance of Missionary Societies) enjoyed a virtual monopoly in educating Kenyans of African origin (Furley and Watson, 1978). Such schools taught basic facts about the Christian religion, and "secular" subjects that lead to apprenticeships in trade or teacher training. Mission schools also enjoyed a monopoly over girl's education as government schools either did not exist (earliest government school was established in 1910), or were reluctant to educate girls' for fear of clashing with local cultural traditions. By the time of the Fraser Report (1919) that urged greater government role in the education of Africans, mission schools were dominant in the coastal, central, and western provinces of Kenya. Their presence was scarcer in 
other regions of the country as they met armed resistance from local tribes (especially in the Rift Valley) who protested their interference in local customs such as female circumcision.

Using primary sources (archives of the CMS housed at the University of Birmingham in the UK) and information in Furley and Watson (1978), we compiled a list of all main mission schools that existed in Kenya from 1844 to 1935 . Missions also established schools in rural areas that were designated "village schools" - we are unable to use this information as all we have are aggregate numbers with no specific locations. From 1844 until 1919, all schools that we have information on are missionary schools that provided access to girls as well as boys, administered knowledge of Christianity and vocational education, and primarily “targeted” Africans. From 1919 until 1935, government schools (segregated by race - European and Asian), and private schools (also segregated by race - starting with the Railway school that was begun in 1907) began to be established. 1935 is the end-point of our data since after that year, mission schools came under the control of the British government (Kenya became a British protectorate in 1895), and although still present in the delivery of elementary education throughout the colony, were no longer active in their original (true) form. The data that we collected over the 1844-1935 time-span has information on 80 schools, including their year of establishment and original location. Among these, 56 are mission schools, 17 are government schools, and 7 are private schools. We use information on location to allocate schools to each of the four locations in our data - Nairobi, Mombasa, Nakuru, and Kisumu.

Mission schools in Kenya were the first to provide elementary education and vocational training, were unique in providing access to girls, and African education was primarily in their hands until 1919. This is important from our point of view since over $70 \%$ of firms in our sample have African principal owners. Gender-based equality in education that mission schools afforded is also important from our view-point since we are interested in how firms with female owners respond differently as compared to their all-male counterparts. It can be argued that mission schools in this time period (and government and primary schools to a smaller extent) laid the foundations for (historical) regional differences in basic skills and knowledge. Beginning from the coastal region, the establishment of mission schools mainly followed 
the growth of the Ugandan Railway (the laying of a railway line from Mombasa to Nairobi, and onwards to Kisumu and then to Uganda, which began in 1895 and was completed in 1901) in their regional distribution. There is thus no systematic correlation between the regional distribution of such schools as of 1935 and the regional distribution of firms in our data. The earliest firm in our data was established in 1920 in Mombasa and as of 1935, only 4 of the 499 firms in our sample had been established. The majority of firms in our sample were established in 2000 , and only $10 \%$ of firms had been established by 1975 , forty years after the end-point of the schools data.

Following Lewis (2010) which uses exogenous variation in the area-specific supply of lessskilled labor as an instrument for technology (automation machinery), we argue that the location of mission schools (mainly) as of 1935 provides regional exogenous variation in the supply of skilled labor which may be used to instrument technology ownership. Using location of schools as of 1935, we allocate each school by distance to the closest point in our data (Nairobi, Mombasa, Nakuru, or Kisumu), and then use this information to construct the share of mission schools among all schools in each of the four regions. Each firm in the data is then allocated a value for its (historical) share of mission schools based on its regional location and start date (year of establishment of the firm). We consider the share variable to be a measure of the historical regional intensity of mission schools. In the discussion that follows, we call this instrument "mission schools" and use its natural log form in the first stage regression. Further, based on the year that the first school was established in each of the four regions (again, these are all mission schools given their dominance in the data in the earlier time periods), we also construct a second related variable that measures (historical) "exposure" to missionary education for each firm based on its regional location and start year. For example, given that the earliest mission school began in Mombasa in 1844, a firm that was established in Mombasa in 2000 would get a value of 154 for this variable. We consider this variable to measure the years of exposure that owners potentially had to the unique education provided by mission schools at the point in time when the firm originated (conditional on location). We refer to this instrument as "exposure to mission schools" and use its natural $\log$ form in the first stage regression. 


\section{Rainfall, average change in forest cover from 2003 to 2005, and average elevation}

In addition to the instruments for (historical) regional skill, we construct three more instruments. These are geographical in nature and relate to total rainfall, change in forest cover between 2003 and 2005, and average elevation in each region. Our use of rainfall as an instrument comes from the observation that operation of computers, generators, and cell-phones depends on having a power source such as electricity. Computers require electricity, and although cell-phones and generators may be battery operated, re-charging of batteries requires electricity. Thus, access to electricity is critical in the operation of the forms of technology we consider.

In Kenya, $60 \%$ of the electricity is generated from hydropower (Kirai, 2009). Kenya Electricity Generating Company (KENGEN), a state-owned national generation company at the time these data were collected, is the main power generator, and controls all publicly owned power plants in Kenya to produce about $80 \%$ of the power consumed in the country (Kirai, 2009). As of 2007, there are fourteen hydropower plants, three thermal plants, two geo-thermal plants, one wind power plant, and two plants that are off-grid in Kenya (see Map 1 for a location of these plants). For each of the plants, we have information on district of location, capacity in megawatts, year of commissioning, river/lake on which the plant is located, and distance to Nairobi. ${ }^{8}$

One of the problems with hydro-electricity is that the quantity of power generated is heavily dependent on the climate, in particular, rainfall. Twelve of the fourteen hydro-plants are located on rivers; six of them on the Tana river in central Kenya - the remaining two hydro-plants are located near lake Victoria and lake Turkana (see Map 1). During times of drought, plants are unable to operate at their peak capacity, and the supply of electricity is disrupted and insufficient. Alternatively, excess rainfall is also a problem because it causes landslides and flooding which destroys power lines.

Using information on year of commissioning and district of location of the power plant, and information on annual rainfall in the four regions of our data, we construct a measure of total rainfall received in the region in which a firm is located. This variable is constructed to allow for a firm's exposure to the rainfall patterns to be dependent on year of origin of the firm and commissioning year of 
the power plant(s) in the region of the firm's location. This is because the rainfall that a firm may "avail" of depends on the year of commissioning of the power plant and the year in which the firm began operations. For example, the earliest plant that was commissioned near Mombasa is Lamu in 1989. Thus firms in Mombasa that had a start year before 1989 get a value of zero for the rainfall variable since no plant existed before that date. Firms with start year of 1989 were affected by the quantity of rainfall received only at Lamu - they thus receive a value of rainfall equal to that in the region in 1989. Two other plants (Kipevu I and Kipevu II) were commissioned near Mombasa in 1999, thus firms that had a start year of 1999 or after are now affected by total rainfall received by the three plants in the Mombasa region in 1989 and 1999. All firms in the data were assigned a value for total regional rainfall based on this method.

Information on historical rainfall from 1901 to 1990 for four stations in Kenya (Machakos (close to Nairobi), Malindi (close to Mombasa), Nakuru, and Kisumu - see map 2 for locations) are available from the Global Historical Climatology Network (GHCN) precipitation data which is part of the National Oceanic and Atmospheric Administration's (NOAA) national climatic data center. Since the Enterprise Survey has information on firms as of 2006, the remaining years of rain data were obtained from UNDP Climate Change Country Profile for Kenya which is available from Oxford University's School of Geography and the Environment. A combination of these two data sources allowed the creation of a historical time series from 1901 to 2006 of annual precipitation data for each of the four regions in our study. These data were then used to construct a firm-level measure of total rainfall (in $\mathrm{mm}$ ) in the region of location of the power plants, conditional on the coincidence of the starting year of the firm and commissioning year of the power station. We denote this variable "rainfall" - the variable measures the quantity of power generated in practice in the region of the firm's location. As in the case of the other two instruments, we use this variable in its natural log form in the first stage regression.

The remaining two instruments (average percentage change in forest cover in each of the four regions from 2003 to 2005, and average elevation of each region) relate specifically to the operation of cell-phones. As is known, cell-phones rely on radio waves, and radio waves do not travel well in regions 
with thick forests or in hilly terrain. We obtain information on change in forest cover (deforestation) from Akotsi et al. (2006), and on average elevation from Fordham and Kinyanjui (1967). We refer to these variables as "change in forest cover" and "average elevation", and each firm is associated with a value for these variables based on its regional location. Change in forest cover is used in its original form in the first stage; we use average elevation in its natural log form in the first stage regression.

Thus, mission schools, exposure to mission schools, rainfall, change in forest cover, and average elevation, are the identifying instruments used to analyze whether ownership of computers, generators, and cell-phones has a beneficial impact on firm productivity. These instruments are correlated to regional historical determinants of basic skills and the regional geographical environment of a firm, and are thus likely to be correlated to the adoption of the forms of technology we consider. Statistical evidence for this is provided in Table 3A which reports the first stage regression results.

\section{First stage regression results}

The first column of Table 3A shows results for all firms in our sample. Four of the five instruments are significant and explain about $15 \%$ of the variation in technology ownership. Mission schools and exposure to mission schools have strong positive effects on technology adoption, consistent with the hypothesis that the historical presence of such schools in the region significantly increased the regional stock of basic skills of the African population. Deforestation at the regional level between 2003 and 2005 has a positive effect on technology; most of this probably arises from the more effective use of cell-phones in the absence of thick forest cover. Finally, average elevation is associated with significantly lower technology ownership; again, a large part of this is most likely due to the fact that cell-phone usage is restricted in areas with elevated terrain. The remaining two columns of Table $3 \mathrm{~A}$ show separate first stages for firms with female principal owners and for firms with only male owners. For firms with female headship, exposure to mission schools has a particularly significant positive effect on technology adoption. Taken with the fact that the magnitude of the effect of mission schools in this sub-sample is the same as in the complete data, there is strong evidence that variables related to mission schools (given their equal attention to boys' and girls' schooling) have power in explaining a sizeable proportion of the 
variation in the adoption of technology by female-owned firms. For the male-only sample, only the share of mission schools appears to matter. The results in Table 3A demonstrate that our identifying instruments are significantly correlated to technology ownership.

Validity of the instruments also rests on demonstrating that conditional on technology, the instruments do not have direct effects on firm productivity. This evidence is presented in Table 3B. The dependent variable in this table is the natural log of value-added per worker, and we focus our discussion on column (2) which includes the full set of firm and industry characteristics. It is clear that conditional on technology, our identifying instruments have no significant effect on value-added per worker. We note that information on value-added per worker is available for 465 of the 499 firms since value-added is exactly zero for 10 firms (so we lose them when we take natural logs), and is not defined for 24 firms (these are micro firms that do not employ any permanent full-time workers; we lose these firms upon dividing by 0 in order to obtain value-added per worker). Taken with the results in Table 3A, the estimates in Table 3B show that the instruments we use are valid.

\section{Second stage regression results}

Before we discuss the instrumental variables results in Table 4, we re-iterate that obstacles are averaged at the region, industry, legal status, and firm size level, in order to avoid bias that might result from using individual perception data. Moreover, technology ownership is also similarly averaged in order to avoid having a first stage with a binary dependent variable. ${ }^{9}$ Such a transformation allows us to use linear TSLS to identify effects. ${ }^{10}$

Table 4 reports the instrumental variables results for technology ownership for all firms, for firms with female owners, and for firms with only male owners. We begin by noting that a test of overidentifying restrictions which tests the joint null hypothesis that the instruments are valid (that is, not correlated with the error term and that the identifying instruments are correctly excluded from the estimated second stage), cannot be rejected in all models of Table 4 (Hansen's J statistic). Next, column

(1) shows that the establishment's ownership of technology has strong, positive, and significant effects on value-added per worker; estimates indicate that technology ownership increases value-added per worker 
by about 86 percentage points. As expected, many obstacles have a negative effect on firm productivity, although only security is measured precisely. Corruption has a counter-intuitive positive effect; however, this category also includes obstacles related to practices of competitors in the informal sector and it is not clear what the total effect of this obstacle should be. The indicator variable for whether the firm has one or more female principal owners in column (1) is insignificant, indicating that conditional on technology ownership and obstacles, firms with female owners are not consistently different from their counter-parts in terms of value-added per worker. The $p$-value of the joint test of the interaction of the female-headship variable with different types of obstacles indicates that the null hypothesis can be rejected. That is, differential patterns in the effects of obstacles exist for female-owned firms. Finally, the $p$-value of the joint test of significance on obstacles indicates that the null hypothesis can be rejected. This implies that conditional on technology ownership, obstacles still exert a non-zero effect on value-added per worker in the full sample of firms.

The second column of Table 4 reports results for the female-owned sample of firms. Technology ownership has significant positive impacts on productivity as measured by value-added per worker. Interestingly, obstacle related to finance is negative and significant in this sub-sample when it was not in the full data. This is consistent with the general observation that female owned firms are relatively more credit-constrained in developing countries. Column (2) indicates that such constraints have measurable limiting effects on productivity. Finally, the $p$-value of the joint test of significance on obstacles indicates that the null hypothesis cannot be rejected. That is, conditional on firm and industry characteristics, female owned firms appear to be able to mute the restrictive influences of business obstacles by investing in technologies such as computers, cell-phones, and generators. This is in contrast to male owned firms (column (3)) where the p-value indicates that the null of joint insignificance can be rejected. In keeping with this result, technology ownership has no significant effect on value-added per worker in the maleonly sub-sample of firms.

The results in Table 4 emphasize the fact that the positive effect of technology ownership on firm productivity in the data arises mainly from the sub-sample of firms with female principal owners. For 
such firms, technology adoption is particularly effective in mitigating the costs associated with business obstacles. For male-owned firms, such patterns are less evident.

\section{Section 7: Conclusion and implications for policy}

Following Menon (2010) which shows that ownership of technologies such as computers, generators, and cell-phones increases when regulatory and infrastructural obstacles pose significant burdens to every-day operations, this study demonstrates that the ownership of such technologies has important measurable effects on firm productivity. An instrumental variables method reveals that net of obstacles, regional, firm, industry, and top manager characteristics, ownership of computers, generators, and cell-phones has large, positive, and significant effects on value-added per worker, mainly for establishments with female principal owners. The magnitude of estimates indicates that for firms with female-headship, technology ownership increases value-added per worker by about 49 percentage points. Strikingly, the ability of technology adoption to mute the impacts of business obstacles related to regulations, infrastructure, security, workforce, corruption, and finance, is evident only for female-owned firms. This suggests that given their relative disadvantages in the economy (smaller-scale, relative isolation from support networks) as compared to male-only owned firms, technology ownership is a particularly effective means of improving productivity for such firms. The results of this study convey that unlike male-owned firms, female-owned firms are able to overcome the debilitating influences of obstacles through investing in computers, cell-phones, and generators.

Our findings indicate that in addition to removing regulatory hurdles, improving physical infrastructure, curbing crime and corruption, and improving security, firms in Kenya may benefit from policies that enable greater technology ownership. A way of fostering this would be to extend access to loans that are relatively low-cost for purposes of purchasing and maintaining computers, generators, and cell-phones for business use. Improving access to loans may be especially relevant for female owned firms for whom finance is likely to be a binding constraint. For example, such loans could be in keeping with the spirit of "Mwamba" loans that are currently provided to women business owners for acquiring machinery by the Kenya Women's Finance Trust, Ltd., but could now also be used for the purchase of 
computers and telecommunication technologies. Mwamba loans are provided to large businesses at present; the results of this study suggest that increasing access of such loans to medium and small firms would be especially fruitful. Furthermore, since operation of technologies is facilitated by a minimum stock of basic skills, the provision of government subsidized vocational training and computer literacy courses would also be of value. Finally, policies that build formal and informal networks among femaleowned businesses would help diffuse expertise on how to use technology to mitigate regulatory burdens in the difficult business environment of Kenya. 


\section{References}

Acemoglu, Daron, Antras, Pol, and Elhanan Helpman. 2007. "Contracts and Technology Adoption." American Economic Review 97(3): 916-943.

Acemoglu, Daron, and David Autor. 2010. "Skills, Tasks, and Technologies: Implications for Employment and Earnings." In Orley Ashenfelter and David Card, eds., Handbook of Labor Economics, Volume 4, Amsterdam: Elsevier-North Holland, forthcoming 2011.

Akotsi, Erick, Gachanja, Michael, and Jacob Ndirangu. 2006. "Changes in Forest Cover in Kenya's five "Water Towers” 2003-2005,"Nairobi: Kenya Forests Working Group.

Alesina, Alberto, and Joseph Zeira. 2009. "Technology and Labor Regulations.” NBER WP 12581.

Almeida, Rita, and Pedro Carneiro. 2009. "Enforcement of Labor Regulation and Firm Size." Journal of Comparative Economics 37(1): 28-46.

Amin, Mohammad. 2009. “Are Labor Regulations Driving Computer Usage in India's Retail Stores?" Economics Letters 102: 45-48.

Angrist, Joshua D., and Alan B. Krueger. 2001. "Instrumental Variables and the Search for Identification: From Supply and Demand to Natural Experiments". Journal of Economic Perspectives 15(4): 6985.

Basant, Rakesh, and Brian Fikkert. 1996. "The Effects of R\&D, Foreign Technology Purchase, and Domestic and International Spillovers on Productivity in Indian Firms," Review of Economics and Statistics 78(2): 187-199.

Besley, Timothy, and Robin Burgess. 2004. "Can Labor Regulations Hinder Economic Performance? Evidence from India”. Quarterly Journal of Economics 2004: 91-134.

Black, Sandra, and Lisa Lynch. 2001. "How to Compete: The Impact of Workplace Practices and Information Technology on Productivity," Review of Economics and Statistics 83(3): 434-445.

Bresnahan, Timothy, Brynjolfsson, Erik, and Lorin Hitt. 2002. "Information Technology, Workplace Organization, and the Demand for Skilled Labor: Firm-Level Evidence," Quarterly Journal of Economics 117(1): 339-376.

Brynjolfsson, Erik, and Lorin Hitt. 2000. "Beyond Computation: Information Technology, Organizational Transformation and Business Performance.” Journal of Economic Perspectives 14(4): 23-48.

Fordham, Paul, and Peter Kinyanjui. 1967. The Geography of Kenya. Nairobi: East Africa Literature Bureau.

Furley, O., and T. Watson. 1978. A History of Education in East Africa. New York, London, Lagos: NOK Publishers.

Goedhuys, Micheline, Janz, Norbert, and Pierre Mohnen. 2006. "What Drives Productivity in Tanzanian Manufacturing Firms: Technology or Institutions?” United Nations University: Working Paper Series No.2006-37. 
Gust, Christopher, and Jaime Marquez. 2004. "International Comparisons of Productivity Growth: The Role of Information Technology and Regulatory Practices," Labour Economics 11: 33-58.

Harding, Torfinn, and Jorn Rattso. 2005. "The Barrier Model of Productivity Growth: South Africa," Norwegian University of Science and Technology: Department of Economics Working Paper No.1/2005.

$\mathrm{Hu}$, Albert, Jefferson, Gary, and Qian Jinchang. 2005. "R\&D and Technology Transfer: Firm-level Evidence from Chinese Industry," Review of Economics and Statistics 87(4): 780-786.

Keller, Maryellen R. 1994. "Productivity and Information Technology: The Elusive Connection," Management Science 40(11): 1406-1425.

Kirai, Paul. 2009. "Kenya Energy Systems: Vulnerability, Adaptation, Resilience,” Paris: Helio International.

Lewis, Ethan. 2010. "Immigration, Skill Mix, and Capital-Skill Complementarity," Quarterly Journal of Economics, forthcoming.

Lall, Somik V., and Taye Mengistae. 2005. "The Impact of Business Environment and Economic Geography on Plant Level Productivity: An Analysis of Indian Industry." World Bank Working Paper WPS3664, Washington DC.

Menon, Nidhiya, and Paroma Sanyal. 2005. "Labor Disputes and the Economics of Firm Geography: A Study of Domestic Investment in India." Economic Development and Cultural Change 53(4): 825-854.

Menon, Nidhiya. 2010. "Obstacles to Business, Technology Use, and Firms with Female Principal Owners in Kenya." Manuscript, Brandeis University.

Mukhopadhyay, Tridas, Surendra, Rajiv, and Kannan Srinivasan. 1997. "Information Technology Impact on Process Output and Quality,” Management Science 43(12): 1645-1659.

Rosenzweig, Mark, and Kenneth Wolpin. 1986. "Evaluating the Effects of Optimally Distributed Public Programs: Child Health and Family Planning Interventions," American Economic Review 76(3): 470-482.

Scarpetta, Stefano, and Thierry Tressel. 2002. "Productivity and Convergence in a Panel of OECD Industries: Do Regulations and Institutions Matter?’OECD: Economics Department Working Paper No. 342.

Stoneman, Paul, and Myung Joong Kwon. 1996. "Technology Adoption and Firm Profitability," Economic Journal 106(437): 952-962.

Varian, Hal. 1992. Microeconomic Analysis. Third Edition. New York, London: W.W. Norton and Co.

Vishwasrao, Sharmila, and William Bosshardt. 2000. "Foreign Ownership and Technology Adoption: Evidence from Indian Firms," Journal of Development Economics 65: 367-387. 
Map 1: Map of power plants in Kenya
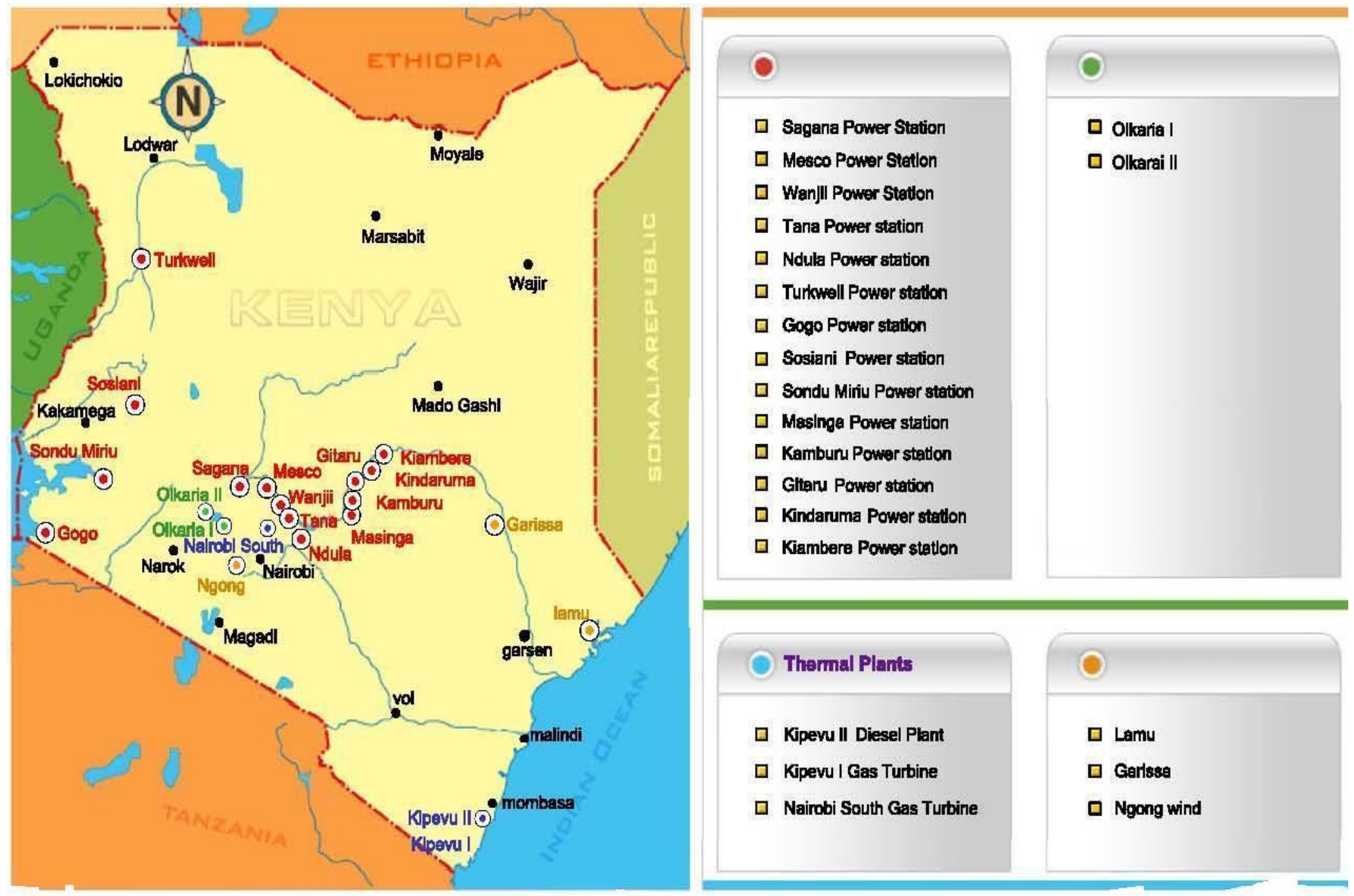

Source: http://www.kengen.co.ke/index.php?page=business\&subpage=powerplant. Accessed on August 17, 2010. 
Map 2: Political map of Kenya



Source: http://www.nationsonline.org/oneworld/map/kenya_map.htm. Accessed on August 12, 2010. 
Figure 1: Percentage of firms with female principal owners and without, by industry

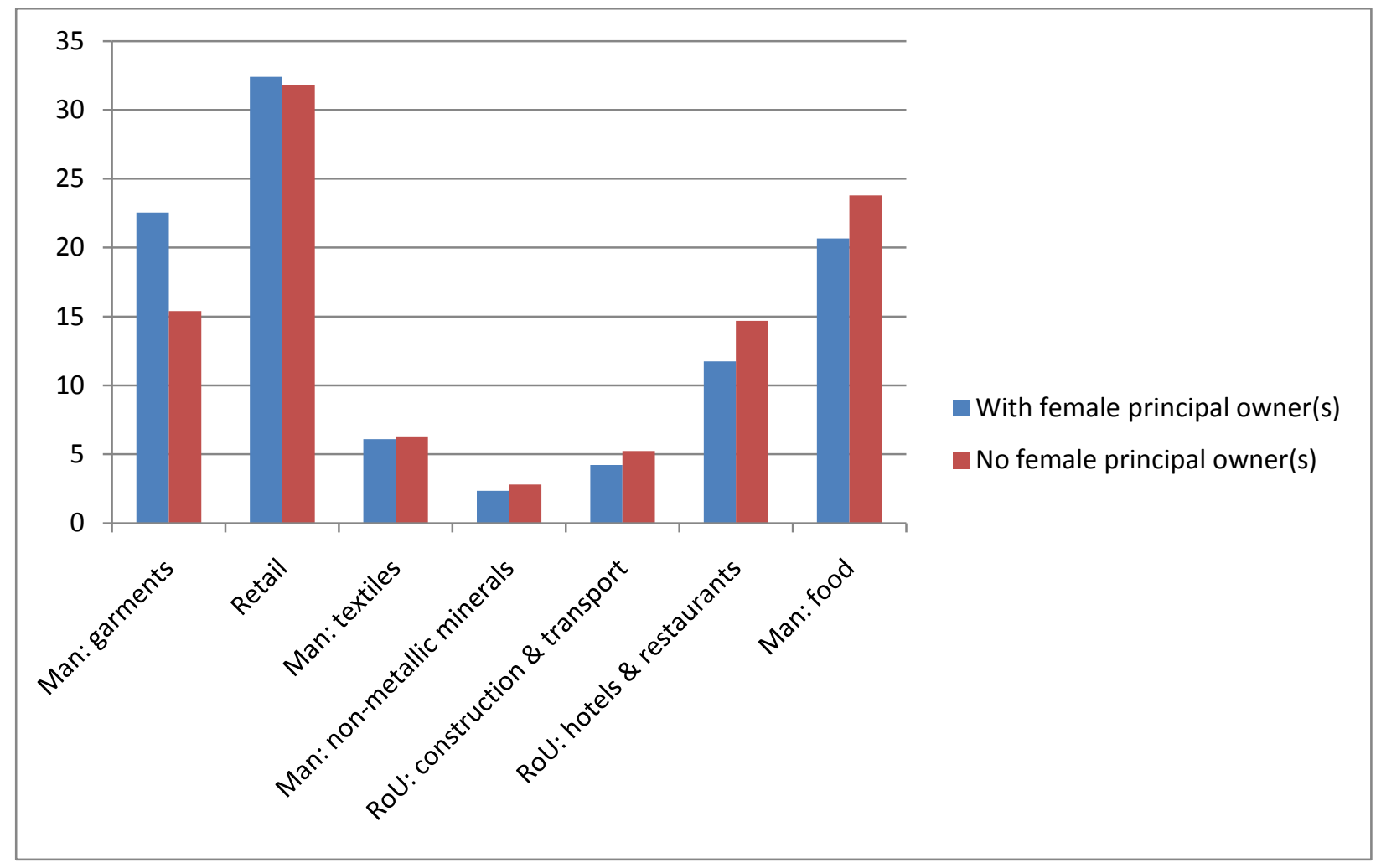

Notes: Industries are arranged by order of the difference between firms with female principal owners and firms with no female principal owners (from largest to smallest), within each industry grouping. 
Figure 2: Percentage of firms with female principal owners and without, by use of technology

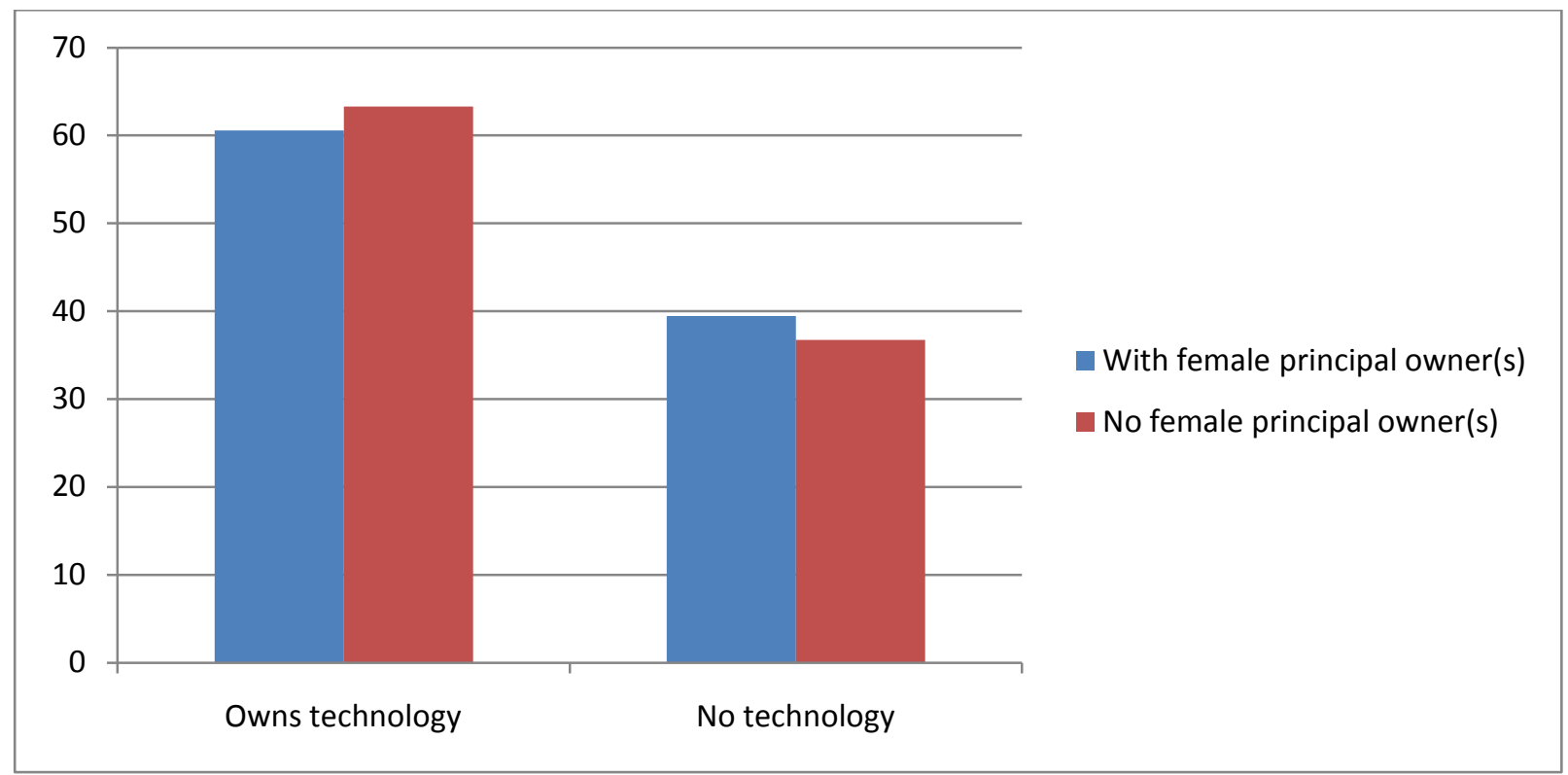

Notes: "Technology" implies that the firm owns a computer (firm uses email or its own website or an internet connection), cell-phone (firm uses a cell-phone for communication with clients and suppliers), or a generator (firm owns or shares a generator). 
Figure 3: Median value-added per worker, by gender of firm owner (2006 US \$)

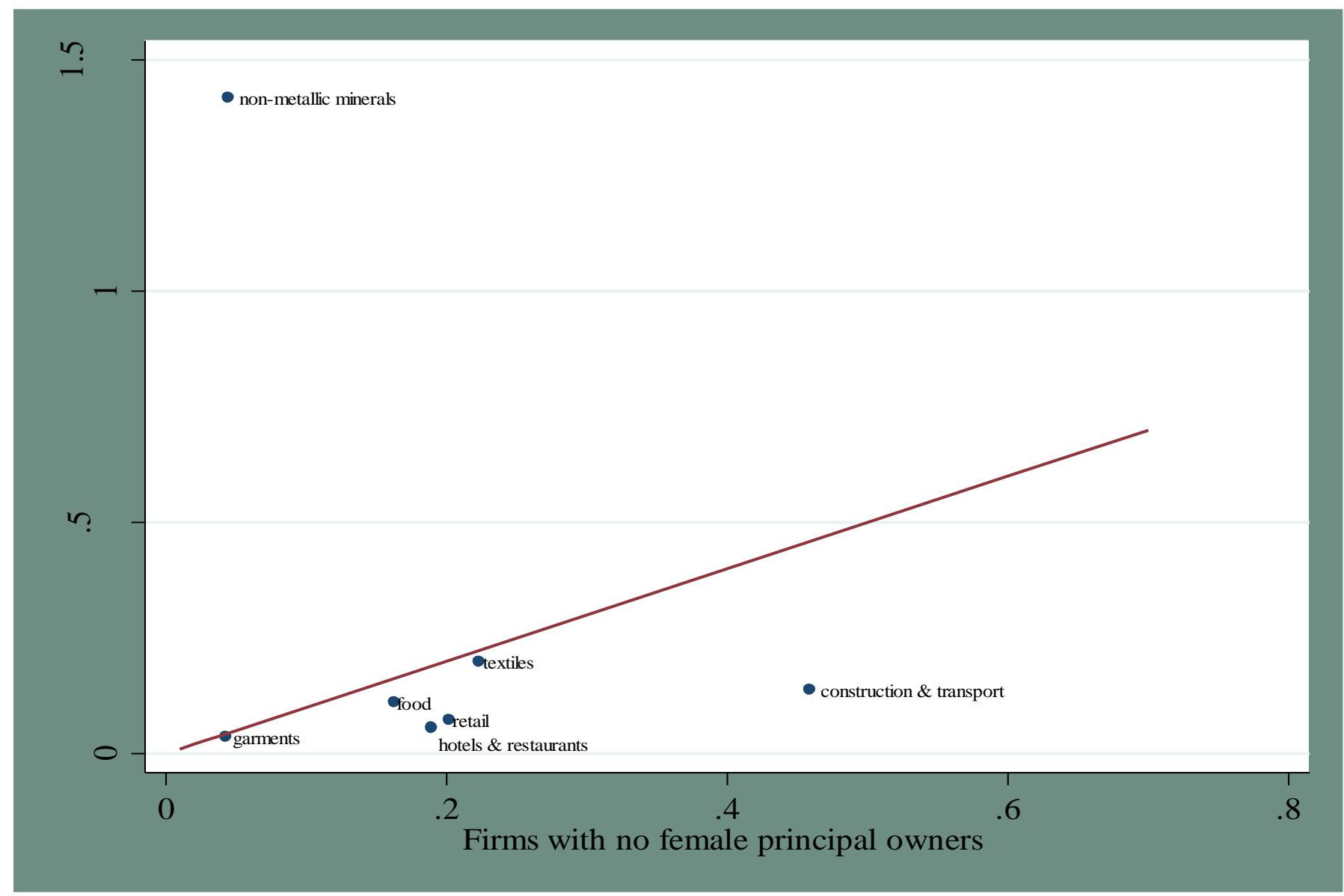


Table 1A: Weighted proportions of firms characterizing obstacles as moderate, major, or very severe

\begin{tabular}{lccc}
\hline Total & $\begin{array}{c}\text { With female } \\
\text { principal owners }\end{array}$ & $\begin{array}{c}\text { No female } \\
\text { principal owners }\end{array}$ \\
\hline $\begin{array}{l}\text { Obstacles related to } \\
\text { regulations }\end{array}$ & 0.997 & 0.998 & 0.999 \\
infrastructure & $(0.001)$ & $(0.002)$ & $(0.00002)$ \\
Security & 0.930 & 0.954 & 0.907 \\
& $(0.004)$ & $(0.034)$ & $(0.037)$ \\
workforce & 0.728 & 0.725 & 0.730 \\
& $(0.095)$ & $(0.143)$ & $(0.050)$ \\
corruption & 0.180 & 0.236 & 0.126 \\
& $(0.082)$ & $(0.127)$ & $(0.021)$ \\
Finance & 0.842 & 0.835 & 0.850 \\
& $(0.059)$ & $(0.053)$ & $(0.068)$ \\
& 0.965 & 0.947 & 0.983 \\
& $(0.020)$ & $(0.036)$ & $(0.006)$ \\
\hline
\end{tabular}

Notes: There are 499 total firms in the sample of which 213 firms have female principal owners and 286 have only male principal owners. Weighted to national level with weights provided by the Enterprise Survey of Kenya. Table reports percentage values. Robust standard errors in parenthesis. 
Table 1B: Weighted proportions of firms characterizing obstacles as moderate, major, or very severe, by industry

\begin{tabular}{|c|c|c|c|c|c|c|c|c|}
\hline & \multicolumn{4}{|c|}{ With female principal owners } & \multicolumn{4}{|c|}{ No female principal owners } \\
\hline & Manufacturing & Retail & $\begin{array}{c}\text { Construction \& } \\
\text { Transport }\end{array}$ & $\begin{array}{l}\text { Hotels \& } \\
\text { Restaurants }\end{array}$ & Manufacturing & Retail & $\begin{array}{l}\text { Construction \& } \\
\text { Transport }\end{array}$ & $\begin{array}{l}\text { Hotels \& } \\
\text { Restaurants }\end{array}$ \\
\hline $\begin{array}{l}\text { Obstacles related to } \\
\text { regulations }\end{array}$ & $\begin{array}{c}1.000 \\
(0.000)\end{array}$ & $\begin{array}{c}0.996 \\
(0.003)\end{array}$ & $\begin{array}{c}1.000 \\
(0.000)\end{array}$ & $\begin{array}{l}1.000 \\
(0.000)\end{array}$ & $\begin{array}{l}1.000 \\
(0.000)\end{array}$ & $\begin{array}{c}0.999 \\
(0.0001)\end{array}$ & $\begin{array}{c}1.000 \\
(0.000)\end{array}$ & $\begin{array}{c}1.000 \\
(0.000)\end{array}$ \\
\hline infrastructure & $\begin{array}{c}0.982 \\
(0.020)\end{array}$ & $\begin{array}{c}0.926 \\
(0.052)\end{array}$ & $\begin{array}{c}0.976 \\
(0.025)\end{array}$ & $\begin{array}{c}0.995 \\
(0.005)\end{array}$ & $\begin{array}{c}0.691 \\
(0.336)\end{array}$ & $\begin{array}{c}0.991 \\
(0.005)\end{array}$ & $\begin{array}{c}0.674 \\
(0.009)\end{array}$ & $\begin{array}{c}0.972 \\
(0.012)\end{array}$ \\
\hline security & $\begin{array}{c}0.997 \\
(0.002)\end{array}$ & $\begin{array}{c}0.639 \\
(0.120)\end{array}$ & $\begin{array}{c}0.995 \\
(0.008)\end{array}$ & $\begin{array}{c}0.714 \\
(0.259)\end{array}$ & $\begin{array}{c}0.771 \\
(0.111)\end{array}$ & $\begin{array}{c}0.645 \\
(0.095)\end{array}$ & $\begin{array}{c}0.995 \\
(0.008)\end{array}$ & $\begin{array}{c}0.967 \\
(0.010)\end{array}$ \\
\hline workforce & $\begin{array}{c}0.006 \\
(0.003)\end{array}$ & $\begin{array}{c}0.334 \\
(0.187)\end{array}$ & - & $\begin{array}{c}0.193 \\
(0.130)\end{array}$ & $\begin{array}{c}0.228 \\
(0.114)\end{array}$ & $\begin{array}{c}0.078 \\
(0.074)\end{array}$ & $\begin{array}{c}0.328 \\
(0.006)\end{array}$ & $\begin{array}{c}0.039 \\
(0.038)\end{array}$ \\
\hline corruption & $\begin{array}{c}0.983 \\
(0.021)\end{array}$ & $\begin{array}{c}0.927 \\
(0.052)\end{array}$ & $\begin{array}{c}0.992 \\
(0.013)\end{array}$ & $\begin{array}{c}0.536 \\
(0.126)\end{array}$ & $\begin{array}{c}0.979 \\
(0.027)\end{array}$ & $\begin{array}{c}0.774 \\
(0.134)\end{array}$ & $\begin{array}{c}1.000 \\
(0.000)\end{array}$ & $\begin{array}{c}0.993 \\
(0.003)\end{array}$ \\
\hline finance & $\begin{array}{c}0.955 \\
(0.045)\end{array}$ & $\begin{array}{c}0.924 \\
(0.051)\end{array}$ & $\begin{array}{c}0.967 \\
(0.033)\end{array}$ & $\begin{array}{c}0.987 \\
(0.010)\end{array}$ & $\begin{array}{c}0.983 \\
(0.010)\end{array}$ & $\begin{array}{c}0.988 \\
(0.007)\end{array}$ & $\begin{array}{c}0.989 \\
(0.006)\end{array}$ & $\begin{array}{c}0.937 \\
(0.027)\end{array}$ \\
\hline
\end{tabular}

Notes: There are 499 total firms in the sample of which 248 are in manufacturing firms, 160 are retail firms, 24 are Construction and Transport firms, and 67 are Hotels and Restaurant firms. Weighted to national level with weights provided by the Enterprise Survey of Kenya. Table reports percentage values. Robust standard errors in parenthesis. 
Table 1C: Weighted proportion of firms characterizing obstacles as moderate, major, or very severe, by use of technology

\begin{tabular}{lcc}
\hline & With female principal owners & No female principal owners \\
& Firm uses email or its own website or an internet connection, or & Firm uses email or its own website or an internet connection, or \\
& firm uses cell-phone for communication with clients and suppliers, & firm uses cell-phone for communication with clients and suppliers, \\
& or firm owns or shares a generator \\
\hline Obstacles related to & & \\
regulations & 0.999 & 1.000 \\
infrastructure & $(0.001)$ & $(0.0001)$ \\
security & 0.957 & 0.909 \\
& $(0.033)$ & $(0.039)$ \\
workforce & 0.727 & 0.731 \\
& $(0.143)$ & $(0.051)$ \\
corruption & 0.237 & 0.126 \\
& $(0.129)$ & $(0.022)$ \\
finance & 0.834 & 0.850 \\
& $(0.053)$ & $(0.069)$ \\
\end{tabular}

Notes: There are 499 total firms in the sample of which 216 firms use email or own website or an internet connection, 69 firms use cell-phones for communication with clients and suppliers, and 13 firms own or share a generator. Weighted to national level with weights provided by the Enterprise Survey of Kenya. Table reports percentage values. Robust standard errors in parenthesis. 
Table 2: Weighted means and standard deviations disaggregated by gender of principal owners

\begin{tabular}{|c|c|c|c|}
\hline & $\begin{array}{l}\text { Firm has at least } \\
\text { one female } \\
\text { principal owner }\end{array}$ & $\begin{array}{l}\text { Firm has no } \\
\text { female } \\
\text { principal owner }\end{array}$ & $\begin{array}{l}\text { Difference } \\
\text { (column } 1 \text { - } \\
\text { column 2) }\end{array}$ \\
\hline \multicolumn{4}{|l|}{ Endogenous variable } \\
\hline Natural log of value added per worker & $\begin{array}{c}1.412 \\
(0.330)\end{array}$ & $\begin{array}{c}2.757 \\
(0.287)\end{array}$ & $\begin{array}{c}-1.346^{* * *} \\
(0.438)\end{array}$ \\
\hline $\begin{array}{l}\text { Firm owns a computer, generator, or } \\
\text { cell-phone }\end{array}$ & $\begin{array}{c}0.976 \\
(0.006)\end{array}$ & $\begin{array}{c}0.961 \\
(0.010)\end{array}$ & $\begin{array}{c}0.015 \\
(0.012)\end{array}$ \\
\hline \multicolumn{4}{|l|}{ Obstacles related to } \\
\hline regulations & $\begin{array}{c}0.999 \\
(0.0004)\end{array}$ & $\begin{array}{c}0.998 \\
(0.0004)\end{array}$ & $\begin{array}{l}0.0003 \\
(0.001)\end{array}$ \\
\hline infrastructure & $\begin{array}{c}0.950 \\
(0.024)\end{array}$ & $\begin{array}{c}0.911 \\
(0.028)\end{array}$ & $\begin{array}{c}0.039 \\
(0.036)\end{array}$ \\
\hline security & $\begin{array}{c}0.749 \\
(0.041)\end{array}$ & $\begin{array}{c}0.706 \\
(0.047)\end{array}$ & $\begin{array}{c}0.043 \\
(0.063)\end{array}$ \\
\hline workforce & $\begin{array}{c}0.190 \\
(0.039)\end{array}$ & $\begin{array}{l}0.170 \\
(0.036)\end{array}$ & $\begin{array}{c}0.020 \\
(0.053)\end{array}$ \\
\hline corruption & $\begin{array}{c}0.819 \\
(0.033)\end{array}$ & $\begin{array}{c}0.865 \\
(0.029)\end{array}$ & $\begin{array}{l}-0.046 \\
(0.044)\end{array}$ \\
\hline finance & $\begin{array}{c}0.968 \\
(0.007)\end{array}$ & $\begin{array}{c}0.962 \\
(0.007)\end{array}$ & $\begin{array}{c}0.006 \\
(0.009)\end{array}$ \\
\hline Instruments & & & \\
\hline $\begin{array}{l}\text { Natural log of total rainfall (in } \mathrm{mm} \text { ) in region } \\
\text { the year firm was established }\end{array}$ & $\begin{array}{c}5.162 \\
(0.514)\end{array}$ & $\begin{array}{c}5.580 \\
(0.504)\end{array}$ & $\begin{array}{l}-0.418 \\
(0.719)\end{array}$ \\
\hline $\begin{array}{l}\text { Average percentage change in forest cover in } \\
\text { region between } 2003 \text { and } 2005\end{array}$ & $\begin{array}{l}13.009 \\
(2.691)\end{array}$ & $\begin{array}{l}18.433 \\
(2.473)\end{array}$ & $\begin{array}{l}-5.424 \\
(3.655)\end{array}$ \\
\hline Natural log of average elevation of region & $\begin{array}{c}3.781 \\
(0.753)\end{array}$ & $\begin{array}{l}5.268 \\
(0.691)\end{array}$ & $\begin{array}{l}-1.487 \\
(1.022)\end{array}$ \\
\hline $\begin{array}{l}\text { Natural log of share of missionary schools (of all } \\
\text { schools) as of } 1935 \text { in region the year firm establish. }\end{array}$ & $\begin{array}{l}-0.474 \\
(0.004)\end{array}$ & $\begin{array}{l}-0.477 \\
(0.004)\end{array}$ & $\begin{array}{c}0.003 \\
(0.006)\end{array}$ \\
\hline $\begin{array}{l}\text { Natural log of years of "exposure" to missionary } \\
\text { schools in region the year firm was established } \\
\text { Regional indicators }\end{array}$ & $\begin{array}{c}4.823 \\
(0.042)\end{array}$ & $\begin{array}{l}4.741 \\
(0.041)\end{array}$ & $\begin{array}{c}0.082 \\
(0.058)\end{array}$ \\
\hline Nairobi & $\begin{array}{c}0.488 \\
(0.101)\end{array}$ & $\begin{array}{c}0.692 \\
(0.093)\end{array}$ & $\begin{array}{l}-0.203 \\
(0.137)\end{array}$ \\
\hline Mombasa & $\begin{array}{c}0.490 \\
(0.102)\end{array}$ & $\begin{array}{c}0.289 \\
(0.093)\end{array}$ & $\begin{array}{c}0.201 \\
(0.138)\end{array}$ \\
\hline Nakuru & $\begin{array}{c}0.013 \\
(0.004)\end{array}$ & $\begin{array}{c}0.010 \\
(0.003)\end{array}$ & $\begin{array}{c}0.003 \\
(0.005)\end{array}$ \\
\hline Kisumu & $\begin{array}{c}0.009 \\
(0.003)\end{array}$ & $\begin{array}{c}0.009 \\
(0.003)\end{array}$ & $\begin{array}{l}-0.001 \\
(0.004)\end{array}$ \\
\hline
\end{tabular}


Table 2: Weighted means and standard deviations disaggregated by gender of principal owner (continued)

\begin{tabular}{|c|c|c|c|}
\hline & $\begin{array}{l}\text { Firm has at least } \\
\text { one female } \\
\text { principal owner }\end{array}$ & $\begin{array}{l}\text { Firm has no } \\
\text { female } \\
\text { principal owner }\end{array}$ & $\begin{array}{l}\text { Difference } \\
\text { (column } 1 \text { - } \\
\text { column 2) }\end{array}$ \\
\hline \multicolumn{4}{|l|}{ Firm and industry characteristics } \\
\hline \multirow{2}{*}{$\begin{array}{l}\text { Natural log of value of machinery (machinery, } \\
\text { vehicle equipment new and/or used) }\end{array}$} & 6.329 & 6.866 & -0.537 \\
\hline & $(0.977)$ & $(0.889)$ & $(1.321)$ \\
\hline \multirow{2}{*}{$\begin{array}{l}\text { Natural log of value of property (land and } \\
\text { buildings) }\end{array}$} & 0.012 & 1.075 & $-1.064 *$ \\
\hline & $(0.006)$ & $(0.554)$ & $(0.554)$ \\
\hline \multirow[t]{2}{*}{ Percent of firm owned by largest shareholders } & 97.162 & 95.723 & 1.440 \\
\hline & $(1.814)$ & (2.464) & $(3.060)$ \\
\hline \multirow[t]{2}{*}{ Dummy for manufacturing firm } & 0.133 & 0.159 & -0.026 \\
\hline & $(0.067)$ & $(0.071)$ & $(0.097)$ \\
\hline \multirow[t]{2}{*}{ Dummy for retail firm } & 0.552 & 0.647 & -0.095 \\
\hline & $(0.101)$ & $(0.090)$ & $(0.135)$ \\
\hline \multirow[t]{2}{*}{ Firm has 20 - 99 employees (“medium” firm) } & 0.006 & 0.010 & -0.004 \\
\hline & $(0.002)$ & $(0.003)$ & $(0.003)$ \\
\hline \multirow[t]{2}{*}{ Firm has 5 - 19 employees (“small” firm) } & 0.020 & 0.029 & -0.009 \\
\hline & $(0.005)$ & $(0.006)$ & $(0.008)$ \\
\hline \multirow[t]{2}{*}{ Firm has African-origin principal owner } & 0.956 & 0.991 & -0.034 \\
\hline & $(0.036)$ & $(0.003)$ & $(0.036)$ \\
\hline \multirow[t]{2}{*}{ Firm has Indian-origin principal owner } & 0.006 & 0.007 & -0.001 \\
\hline & $(0.002)$ & $(0.002)$ & $(0.003)$ \\
\hline \multicolumn{4}{|l|}{ Top manager's characteristics } \\
\hline \multirow[t]{2}{*}{ Illiterate } & - & 0.00004 & -0.00004 \\
\hline & & $(0.00004)$ & $(0.00004)$ \\
\hline \multirow[t]{2}{*}{ Some primary or primary school graduate } & 0.341 & 0.224 & 0.117 \\
\hline & $(0.097)$ & $(0.081)$ & $(0.126)$ \\
\hline \multirow[t]{2}{*}{ Some secondary or secondary school graduate } & 0.591 & 0.618 & -0.027 \\
\hline & $(0.099)$ & $(0.092)$ & $(0.135)$ \\
\hline \multirow[t]{2}{*}{ Vocational training } & 0.013 & 0.098 & -0.085 \\
\hline & $(0.004)$ & $(0.056)$ & $(0.056)$ \\
\hline \multirow[t]{2}{*}{ Some university training or graduate degree } & 0.051 & 0.057 & -0.006 \\
\hline & $(0.036)$ & $(0.035)$ & $(0.050)$ \\
\hline \multirow[t]{2}{*}{ MBA or PhD from Kenya or another country } & 0.004 & 0.003 & 0.001 \\
\hline & $(0.002)$ & $(0.001)$ & $(0.002)$ \\
\hline \multirow[t]{2}{*}{ Years of managerial experience in this sector } & 7.598 & 7.326 & 0.272 \\
\hline & $(1.027)$ & $(1.289)$ & $(1.648)$ \\
\hline
\end{tabular}

Notes: Weighted to national level with weights provided by the Enterprise Survey for Kenya. Table reports percentage values. Standard errors in parentheses. The notation ${ }^{* * *}$ is $\mathrm{p}<0.01,{ }^{* *}$ is $\mathrm{p}<0.05,{ }^{*}$ is $\mathrm{p}<0.10$. 
Table 3A: First stage regressions for identifying instruments

\begin{tabular}{|c|c|c|c|}
\hline & $\begin{array}{c}\text { All firms } \\
\text { (1) }\end{array}$ & $\begin{array}{l}\text { a computer, cell- } \\
\text { Firms with } \\
\text { female owners } \\
\text { (2) }\end{array}$ & $\begin{array}{l}\text { or generator } \\
\text { Firms with no } \\
\text { female owners } \\
\text { (3) }\end{array}$ \\
\hline \multicolumn{4}{|l|}{ Instruments } \\
\hline Natural log of total rainfall (in $\mathrm{mm}$ ) in region & -0.001 & -0.003 & 0.0003 \\
\hline the year firm was established & $(0.001)$ & $(0.002)$ & $(0.0003)$ \\
\hline Average percentage change in forest cover in & $0.012 * * *$ & $0.012 * * *$ & $0.013 * * *$ \\
\hline region between 2003 and 2005 & $(0.00003)$ & $(0.0001)$ & $(0.00005)$ \\
\hline Natural log of average elevation of region & $-0.039 * * *$ & $-0.022 *$ & $-0.050 * * *$ \\
\hline & $(0.003)$ & $(0.012)$ & $(0.002)$ \\
\hline Natural log of share of missionary schools (of all & $0.020 * * *$ & $0.020 * * *$ & $0.023 * * *$ \\
\hline schools) as of 1935 in region the year firm establish. & $(0.001)$ & $(0.003)$ & $(0.0001)$ \\
\hline Natural log of years of "exposure" to missionary & $0.121 * *$ & $0.381 * *$ & -0.032 \\
\hline schools in region the year firm was established & $(0.401)$ & $(0.191)$ & $(0.032)$ \\
\hline R-squared & 0.145 & 0.207 & 0.116 \\
\hline Observations & 499 & 213 & 286 \\
\hline
\end{tabular}

Notes: Weighted to national level with weights provided by the Enterprise Survey for Kenya. Table reports OLS regressions. Standard errors, clustered by region, in parentheses. The notation ${ }^{* * * *}$ is $p<0.01,{ }^{* *}$ is $p<0.05,{ }^{*}$ is $\mathrm{p}<0.10$. Regressions include a constant term. 
Table 3B: Regressions for value-added per worker and identifying instruments conditional on technology

\begin{tabular}{|l|cc|}
\hline & \multicolumn{2}{|c|}{ Natural log of value added per worker } \\
\hline Firm owns computer, cell-phone, or generator & $(1)$ & $1.533 * *$ \\
& -1.084 & $(0.494)$ \\
Total rainfall (in mm) in region the year firm was & $(0.345)$ & -0.005 \\
established & -0.002 & $(0.007)$ \\
Average percentage change in forest cover in & $(0.005)$ & -0.009 \\
region between 2003 and 2005 & 0.037 & $(0.125)$ \\
Natural log of average elevation of region & $(0.065)$ & 0.338 \\
& 0.030 & $(0.393)$ \\
Natural log of share of missionary schools (of all & $(0.294)$ & -3.314 \\
schools) as of 1935 in region the year firm establish. & 0.068 & $(2.401)$ \\
Natural log of years of "exposure" to missionary & $(0.450)$ & -2.197 \\
schools in region the year firm was established & -1.356 & $(4.595)$ \\
& $(3.354)$ & YES \\
Includes obstacles, region, firm, industry and top & & 0.305 \\
manager characteristics & $\mathrm{N} 0$ & 464 \\
R-squared & & \\
Observations & 0.077 & 465 \\
\end{tabular}

Notes: Weighted to national level with weights provided by the Enterprise Survey for Kenya. Table reports OLS regressions. Standard errors, clustered by region, in parentheses. The notation ${ }^{* * *}$ is $\mathrm{p}<0.01,{ }^{* *}$ is $\mathrm{p}<0.05,{ }^{*}$ is $\mathrm{p}<0.10$. Regressions include a constant term. 
Table 4: Instrumental variables results for the effect of technology on value added per worker

\begin{tabular}{|c|c|c|c|}
\hline & \multicolumn{3}{|c|}{ Natural log of value added per worker } \\
\hline & All firms & Has female owners & No female owners \\
\hline \multirow[t]{2}{*}{ Firm owns a computer, generator, or cell-phone } & $86.224 * *$ & $49.064 * *$ & 7.275 \\
\hline & $(41.097)$ & $(23.227)$ & $(5.672)$ \\
\hline \multirow[t]{2}{*}{ Obstacles related to regulations } & -34.232 & 7.000 & $7.094 * *$ \\
\hline & $(29.187)$ & $(16.020)$ & $(3.394)$ \\
\hline \multirow[t]{2}{*}{ Obstacles related to infrastructure } & 5.209 & -1.212 & 0.041 \\
\hline & $(4.771)$ & $(2.947)$ & $(0.828)$ \\
\hline \multirow[t]{2}{*}{ Obstacles related to security } & $-24.196 * * *$ & $-9.582 *$ & -2.146 \\
\hline & $(8.880)$ & $(5.087)$ & $(1.328)$ \\
\hline \multirow[t]{2}{*}{ Obstacles related to workforce } & -10.430 & 3.968 & 1.433 \\
\hline & $(6.569)$ & $(2.489)$ & $(1.015)$ \\
\hline \multirow[t]{2}{*}{ Obstacles related to corruption } & $41.766 * *$ & $10.816^{* * *}$ & 3.754 \\
\hline & $(16.550)$ & $(1.683)$ & $(2.632)$ \\
\hline \multirow[t]{2}{*}{ Obstacles related to finance } & -0.071 & $-6.799 * * *$ & 0.224 \\
\hline & $(8.145)$ & $(2.626)$ & $(0.675)$ \\
\hline \multirow[t]{2}{*}{ Firm has one or more female principal owners } & -20.325 & & \\
\hline & $(16.394)$ & & \\
\hline \multicolumn{4}{|l|}{ Female principal owner interactions with: } \\
\hline \multirow[t]{2}{*}{ Obstacles related to regulations } & 43.861 & & \\
\hline & $(36.370)$ & & \\
\hline \multirow[t]{2}{*}{ Obstacles related to infrastructure } & -4.775 & & \\
\hline & $(7.306)$ & & \\
\hline \multirow[t]{2}{*}{ Obstacles related to security } & $11.068 *$ & & \\
\hline & $(6.118)$ & & \\
\hline \multirow[t]{2}{*}{ Obstacles related to workforce } & 15.183 & & \\
\hline & $(10.533)$ & & \\
\hline \multirow[t]{2}{*}{ Obstacles related to corruption } & $-25.424 *$ & & \\
\hline & $(14.870)$ & & \\
\hline \multirow[t]{2}{*}{ Obstacles related to finance } & -9.958 & & \\
\hline & $(8.528)$ & & \\
\hline \multirow{2}{*}{$\begin{array}{l}\chi^{2} \text { value of joint test of significance of } \\
\text { obstacles }\end{array}$} & 12.35 & 3.67 & 308.13 \\
\hline & {$[0.006]$} & {$[0.299]$} & {$[0.000]$} \\
\hline \multirow{2}{*}{$\begin{array}{l}\chi^{2} \text { value of joint test of significance of female } \\
\text { principal owner and obstacles }\end{array}$} & 32.84 & & \\
\hline & {$[0.000]$} & & \\
\hline \multirow[t]{2}{*}{ Hansen's J Statistic } & 2.043 & 2.644 & 0.285 \\
\hline & {$[0.360]$} & {$[0.450]$} & {$[0.593]$} \\
\hline \multirow{2}{*}{$\begin{array}{l}\text { Includes region, firm, industry, and manager chars. } \\
\text { Observations }\end{array}$} & YES & YES & YES \\
\hline & 464 & 200 & 264 \\
\hline
\end{tabular}

Notes: Weighted to national level with weights provided by the Enterprise Survey for Kenya. Table reports two stage least squares estimates. Standard errors, clustered by region, in parentheses. $p$-values in square brackets. The notation ${ }^{* * *}$ is $\mathrm{p}<0.01,{ }^{* *}$ is $\mathrm{p}<0.05,{ }^{*}$ is $\mathrm{p}<0.10$. Regressions include a constant term. 


\section{Endnotes}

${ }^{1}$ Given data constraints, we do not model the choice of whether to invest in technologies such as computers, generators, and cell-phones in this study (this is a topic of future work). Here, we assume that this decision is economically rational for firms that own such technologies, that is, the net benefit from the ownership of such technologies is positive for these firms.

${ }^{2}$ As noted in Bresnahan et al. (2002). In so far as the general effect of technology is likely to be beneficial on the whole (increase the efficiency of production and reduce input costs), we consider the magnitude of the short-run effects measured here to be an underestimate of long-run adjustments in the future. Data permitting, our objective in subsequent work is to study this long-run adjustment.

${ }^{3}$ Modeling technology adoption as a reduction in price is similar to the intuition provided in Rosenzweig and Wolpin (1986).

${ }^{4} \mathrm{We}$ assume that the total factor productivity parameter equals one. One way to incorporate long run effects of technology ownership on production process and input choice would be to condition total factor productivity as a function of technologies owned, similar to Hu and Jefferson (2005).

${ }^{5}$ For example, there is still a bill for services provided by the cell-phone.

${ }^{6}$ See Menon (2010) for a disaggregation of effects relevant to each.

${ }^{7}$ This is similar to the methodology in Amin (2009).

${ }^{8}$ These data are available from the KENGEN website at http://www.kengen.co.ke/.

${ }^{9}$ Results in Tables 3A and 3B use technology in its averaged form.

${ }^{10}$ We report coefficients from TSLS and then use STATA's ivreg2 procedure to obtain a value for Hansen's J statistic. 